ENTREPRENEURSHIP AND SUSTAINABILITY ISSUES

ISSN 2345-0282 (online) http://jssidoi.org/jesi/

2019 Volume 6 Number 3 (March)

http://doi.org/10.9770/jesi.2019.6.3(7)

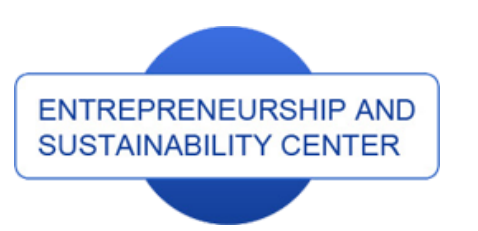

Publisher

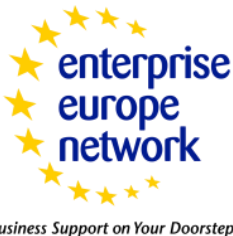

CASPA

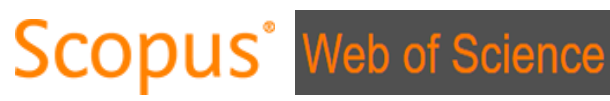

http://jssidoi.org/esc/home

Business Support on Your Doorstep

1) Clarivate

Analytics

\title{
SOCIAL ENTERPRISES: EVALUATION OF THE IMPACT OF STATE SUPPORT AND CORPORATE INCOME EXEMPTIONS ON THE STATE BUDGET OF LITHUANIA
}

\author{
Rasa Subačiene் $\dot{1}^{1}$ Ramunė Budrionyte் ${ }^{2}$, Aida Mačerinskiene் $\dot{e}^{3}$, Daiva Tamulevičiené $\dot{4}^{4}$ \\ 1,2,3,4 Vilnius University, Sauletekio al. 9, Vilnius, LT-10222, The Republic of Lithuania \\ E-mails: ${ }^{1}$ rasa.subaciene@evaf.vu.lt; ${ }^{2}$ ramune.budrionyte@evaf.vu.lt; ${ }^{3}$ aida.macerinskiene@evaf.vu.lt; \\ 4daiva.tamuleviciene@evaf.vu.lt
}

Received 15 November 2018; accepted 20 January 2019; published 30 March 2019

\begin{abstract}
The increasing interest in social enterprises is related to the specifics of their business activities, which not only involve the most vulnerable part of the society, but also offer greater opportunities for the socialisation of the disadvantaged. As a rule, social enterprises may be entitled to some tax exemptions or may apply for the specific state support. Such tools help to reduce the low efficiency of social enterprises and extend possibilities for the most vulnerable part of the society to participate in the creation of the general economic value of enterprises and the country as a whole. The recent changes introduced in Lithuania reduced the level of the state support and the exemptions from corporate income tax for social enterprises under the impact of the opinion that such enterprises may misuse the status of social enterprises and, accordingly, the state support tools. Therefore, such changes raise the need to evaluate their possible influence on the state budget of Lithuania. The purpose of the research is to evaluate the impact of state support and corporate income exemptions for social enterprises, on the state budget of Lithuania. The object of the research - involves the data of income statements of social enterprises, the information on state support, the state budget of Lithuania for the period of $2013-2017$. The research deployed the legislation analysis, the inductive and deductive methods, the methods of systematisation, comparison and summary of information. The research results show that the value of corporate income tax exemptions and state support do not have a significant impact on the state budget of Lithuania and reach around the average of $0.18 \%$ of the state budget. Nevertheless, the reduction of state support and corporate income tax exemptions may limit the possibilities of social enterprises to reinvest their profits, expand businesses and employ marginalised population.
\end{abstract}

Keywords: social enterprises; state support; corporate income tax exemptions; Lithuania

Reference to this paper should be made as follows: Subačienè, R.; Budrionytė, R.; Mačerinskienè, A.; Tamulevičienė, D. 2019. Social enterprises: evaluation of the impact of state support and corporate income exemptions on the state budget of Lithuania, Entrepreneurship and Sustainability Issues 6(3): 1156-1171. http://doi.org/10.9770/jesi.2019.6.3(7)

JEL Classifications: M10, D20 


\section{ENTREPRENEURSHIP AND SUSTAINABILITY ISSUES}

ISSN 2345-0282 (online) http://jssidoi.org/jesi/

2019 Volume 6 Number 3 (March)

http://doi.org/10.9770/jesi.2019.6.3(7)

\section{Introduction}

The interest in social enterprises is consistent with the increasing demand imposed on business organisations to trigger positive social changes by engaging in social and environmental initiatives. However, traditional business organisations keep social value creation at the periphery of their operations and engage in social projects to protect and complement the core objective of wealth generation. Differently, in social enterprises, social value creation is central to their operations because these ventures employ a market-based organisational form with the purpose of creating positive changes in the society, thus being at the intersection between the traditional "business" and "charity" model (Ramus, Vaccaro, 2017). This model emphasises several most important aspects of social enterprises: the involvement of the most vulnerable part of the society in business activities and greater socialisation of this part of the society. Thus, the role and importance of social enterprises in the economic and social systems of any country should be most significant. According to their importance, social enterprises usually have some tax exemptions or may apply for the specific state support. These tools not only help to reduce the low efficiency of social enterprises, but also offer possibilities for the most vulnerable part of the society to participate in the creation of the general economic value of the enterprises and the country as a whole. The latest political discussions observed in Lithuania have initiated several governmental decisions leading to the reduction of the level of state support and the exemptions from the corporate income tax to social enterprises under the assumption that such enterprises may misuse the status of social enterprises and, accordingly, the state support tools. Therefore, these changes raise the need to evaluate their possible influence on the state budget.

The purpose of this research is to evaluate the impact of state support and corporate income exemptions provided for social enterprises on the state budget of Lithuania. The object of the research is the- data of income statements of social enterprises, information on the state support, the state budget of Lithuania over the period from 2013 through 2017. The research deployed the legislation analysis, the inductive and deductive methods, the methods of systematisation, comparison and summary of information.

\section{The research methodology}

Figure 1 presents the methodology of the research carried out in several phases to evaluate the impact of the state support and corporate income tax exemptions, provided for social enterprises, on the state budget of Lithuania. The first phase involved the examination of the concept of social enterprises based on the analysis of the opinions and research findings obtained by the Lithuanian and foreign scientists. The second and third phases included the analysis and evaluation of the Lithuanian condition of social enterprises, the state support and corporate income tax exemptions provided for social enterprises. 
ENTREPRENEURSHIP AND SUSTAINABILITY ISSUES

ISSN 2345-0282 (online) http://jssidoi.org/jesi/

2019 Volume 6 Number 3 (March)

http://doi.org/10.9770/jesi.2019.6.3(7)

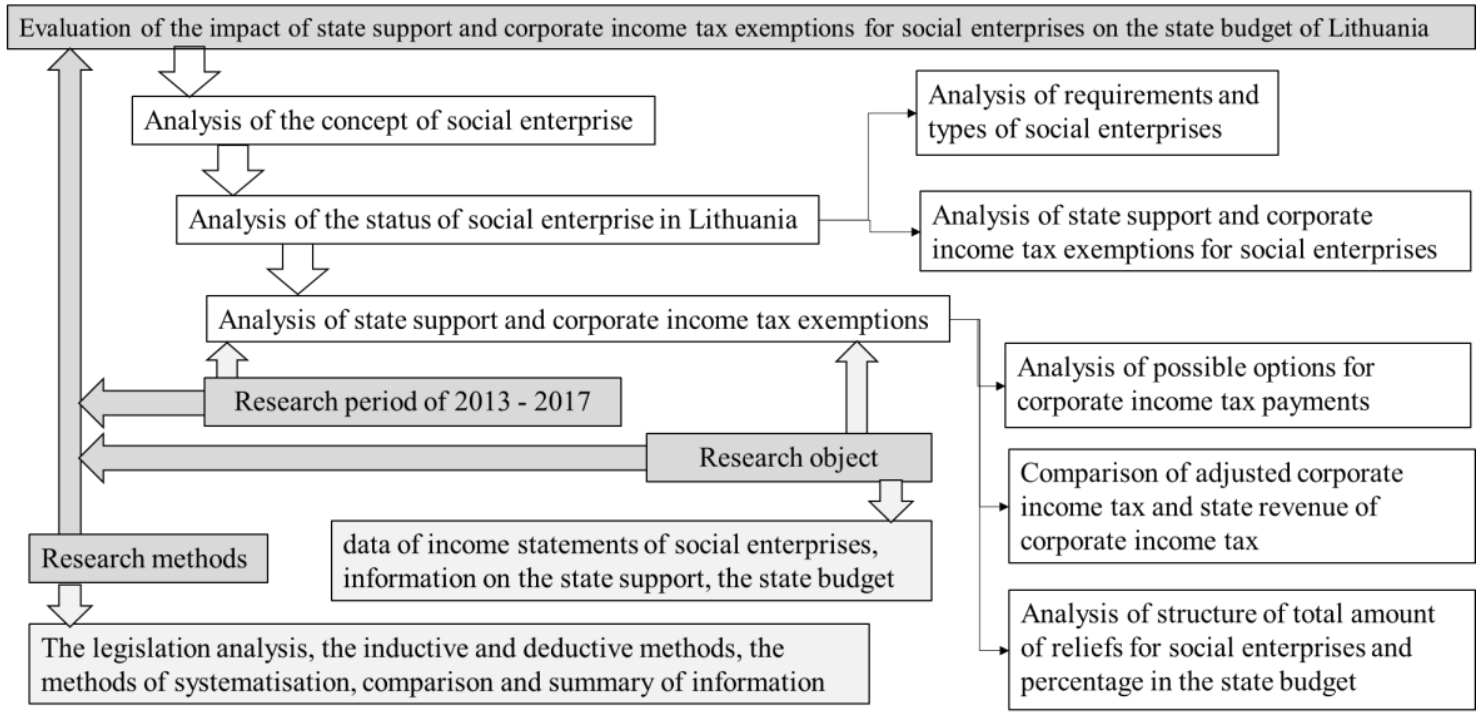

Fig. 1. The research methodology

Source: composed by authors

The evaluation of the impact of state support and corporate income tax exemptions for social enterprises on the state budget of Lithuania was carried out on the basis of the analysis of income statements of social enterprises, the information obtained from of the Lithuanian Labour Exchange on different types of state support provided for social enterprises and the information on the state budget of Lithuania for the period of the last five years. The total amount of social enterprises in 2017 was 189 (The Lithuanian Labour Exchange, 2018). In order to meet the target of the research, the selection criterion of possessing the status of a social enterprise over the entire research period was set. In all, 99 social enterprises complied with the criteria and were selected for the research. The income statements of the selected enterprises for the period of 2013-2017 were provided by the Credit Bureau "Creditinfo".

\section{The concept of a social enterprise}

Social enterprises are vital legal entities in the economy of any country. These enterprises involve the disabled persons and other most vulnerable persons of the society not only in terms of the creation of the general economic value of the country, but also play a crucial role in the participation of the individuals in the social life and the activities of communities. These aspects emphasize the need to analyse the concept of social enterprises and the impact of their activity.

Social enterprises may be of different legal forms, but should meet several criteria to have the status of a social enterprise. In general, according to A. Szymanska, M. Jegers (2016, p. 502), there are three generic forms of organisations: governments, profit organisations and non-profit organisations. A social enterprise is one of the possible hybrid forms. The EMES (International Research Network) claims that social enterprises should satisfy the following criteria: they operate continuously, have a high autonomy, have a considerable level of risk, and employ a minimum number of paid workers (Szymanska, Jegers, 2016, p. 502).

M. P. Miles, M.-L. Verreynne and B. Luke (2014) argue that social enterprises are organisations with an overarching core social mission funded through market-based initiatives. They exist to serve their beneficiaries and are increasingly being relied upon to provide essential social services as government services decline. The authors call social enterprises as hybrid organisations established for a social purpose, using a for-profit business 


\section{ENTREPRENEURSHIP AND SUSTAINABILITY ISSUES}

ISSN 2345-0282 (online) http://jssidoi.org/jesi/

2019 Volume 6 Number 3 (March)

http://doi.org/10.9770/jesi.2019.6.3(7)

model to generate the financial resources needed to support their social missions. As unmet social needs become more critical, social enterprises are seeking to become more efficient and effective in their operations and strategies to fulfil their missions (Miles, Verreynne, Luke, 2014).

B. Gidron, Y. Monnickendam-Givon (2017, p. 128) provide a simple definition of social enterprises; it is most commonly described (in different variations) as an organisation that pursues a social mission through the use of market mechanisms. The authors also state, that social enterprises are organisations-companies - that aim to provide social services but they can accomplish this task only if they can ensure their financial viability to operate. They think that the concept of 'social enterprise' is not new and has been presented and discussed in the literature for a long time, mostly in the context of the developing countries. By and large it pertains to entities that combine commercial and social objectives. (Gidron, Monnickendam-Givon, 2017, p. 127).

V. Pestoff and L. Hulga (2015, p. 1752) state that despite more than a decade of intensive discussion, a precise definition of social enterprises at the EU level does not exist yet. According to EMES, a social enterprise's economic project comprises a continuous production of a good or service, based on some paid work, and it takes an economic risk (Pestoff, Hulga, 2015, p. 1752). The authors conclude that much of the American academic debate about social enterprises fails to take into account the political or governance dimensions at the center of the collective efforts of the EMES network of European scholars to promote a better understanding of social enterprises. The EMES network has extensively discussed and developed nine ideal types of criteria for defining and delimiting social enterprises - three economic, three political and three social criteria (Pestoff, Hulga, 2015, p. 1754). Three indicators reflect the economic and entrepreneurial dimensions of social enterprises: a) a continuous activity producing goods and/or selling services; b) a significant level of economic risk; c) a minimum amount of paid work. Three indicators encapsulate the social dimensions of such enterprises: a) an explicit aim to benefit the community; b) an initiative launched by a group of citizens or civil society organisations; c) a limited profit distribution. Three indicators reflect the participatory governance of such enterprises: a) a high degree of autonomy; b) a decision-making power not based on capital ownership, c) a participatory nature which involves various parties affected by the activity (Social enterprise, 2018).

B. Gidron and Y. Monnickendam-Givon (2017, p. 128) also refer to the EMES network and state that this network has engaged in studying the concept of social enterprises for the past two decades and has developed an 'ideal-type' approach to define the concept. Their definition is composed of three components: (i) the economic and entrepreneurial dimensions, which, practically, suggest that the entity engages in commercial activities of selling a product or a service and competing in the market; (ii) the social dimensions, which have to do with the contribution to the community - the raison d'être of the entity; and (iii) the participatory governance dimensions, which provide an expression of community ownership (Gidron, Monnickendam-Givon, 2017, p. 128). The authors conclude, based on the results of their research, that in recent years a growing number of market-oriented social enterprises have been formed in the world of social welfare. Many of these provide employment for marginalised populations, mostly people with disabilities, where the participants are treated as workers, receive a regular salary and enjoy the same benefits as other workers (the social goal). These entities produce a product or provide a service that is sold and competes on the market (the business strategy). Obviously, the product or the service produced or provided fits the specific abilities of the employed population, which calls for an enterprise that is created around those abilities, benefitting the specific participants rather than trying to fit marginalised populations into existing jobs in the existing 'regular' organisations. While such entities often build on the tradition of the Work Integration Social Enterprises (WISEs) programmes, sponsored by governments in Europe and the United States in the 1990s, the new wave of such social enterprises are products of entrepreneurial activities by social and business entrepreneurs and take a variety of organisational and legal forms (Gidron, Monnickendam-Givon, 2017, p. 128). 


\section{ENTREPRENEURSHIP AND SUSTAINABILITY ISSUES}

ISSN 2345-0282 (online) http://jssidoi.org/jesi/

2019 Volume 6 Number 3 (March)

http://doi.org/10.9770/jesi.2019.6.3(7)

A. Chan (2016, p. 1719-1720) describes social purpose enterprises like ordinary commercial entities that generate income through the exchange of goods and services, but operate with the added social objective of providing work opportunities to people who have experienced persistent difficulties finding or maintaining employment. The author states that these enterprises are often noted for their 'supportive' nature that accommodates the social and economic situations as well as the employment history and the skill level of their workers. They provide employment and job training to individuals with complex and often multiple challenges to work which include but are not limited to poor health, physical, psychiatric and developmental disabilities, insecure housing, limited formal education or work experience, language barrier, newcomer adjustment challenges, unaffordable childcare, and domestic violence (Chan 2016, p. 1719-1720). A. Chan (2016, p. 1720) presents information that the work opportunities in Canada can be part-time or full-time, short-term or permanent, these ventures are primarily notfor-profit and belong to any number of industries (e.g. food services, construction, courier services, bicycle repair, printing, recycling), including some that also provide micro-entrepreneurship training and support. Although they generate revenue through sales on the market or service contracts with the state, in most cases these organisations remain heavily reliant on other government funding, foundation grants, and volunteer support. They are often supported by a parent nonprofit organisation (Chan, 2016, p. 1719-1720).

According to Y- Ch. Cho and J.- H. Jang, (2014) in any case, social enterprises are generally understood in terms of a business model which meets both social and economic objectives, contributing to labour market integration and social cohesion (Cho, Jang, 2014, p. 119). The authors summarise that there are two key requirements for any enterprise to become a certified social enterprise in Korea. First, its primary business motivation must be the common good. Second, the primary business activity must be to manufacture a product and sell a service. Social enterprises in Korea should sell goods or provide services in the market for the purpose of generating income just like other enterprises, but their business motivation is to realize a social purpose rather than to maximise profits to shareholders. Therefore, social enterprises are expected to provide vocational training opportunities and jobs for vulnerable members of the society, protect and improve the environment, educate young people and expand social services for low-income and disadvantaged persons (Cho, Jang, 2014, p. 120).

According to V. Pestoff and L. Hulga (2015, p. 1751) the US social enterprises can take a number of different legal forms, while nonprofit organisations, on the other hand, are recognised and defined by law and they have a preferred status under the US tax law. In Europe, by contrast, the policy and legal context appears much more conducive to the development of social enterprises as welfare actors, given their more institutional nature. Moreover, European legal frameworks reflect specific legal traditions, welfare regimes, and economic issues dealt with at the national level (Pestoff, Hulga, 2015, p.1751). Thus governance structures have quite naturally attracted much more attention in Europe than elsewhere. In fact, it could be argued that the emphasis given to the governance issue perhaps reflects the most distinctive contribution of the EMES approach to date. Moreover, governance structure can also be seen as an organisational device to ensure the sustainable pursuit of a social enterprise's social mission (Pestoff, Hulga, 2015, p. 1754-1755).

T. Ramus and A. Vaccaro (2017) conclude that given their characteristics, social enterprises can be extremely successful in addressing complex social issues because they combine the efficiency and resources of the traditional business model with the sense of mission of the charity one (Ramus, Vaccaro, 2017).

J. Čižikienè and A. Urmanavičienè-Čižikaitè (2013, p. 27) refer to the EESC (The European Economic and Social Committee) that proposes to distinguish the characteristics of a social enterprise as follows: achieves social objectives rather than profit, has a variety of legal forms and models (cooperatives, mutual societies, voluntary associations, foundations, profit or non-profit companies); is engaged in business activities based on democratic principles including employees, customers and members of the general decision-making and management (Čižikienè, Urmanavičienè-Čižikaitè, 2013, p. 27). 
V. Pestoff and L. Hulga (2015, p. 1755) state that it is widely recognised that the role of governance structure is a key issue in the European discussion of social enterprises, too (Pestoff, Hulga, 2015, p. 1755). Governance is also coming increasingly under scrutiny in many social science disciplines by becoming a key theoretical concept, not merely a normative prescription. Thus, the political dimension of social enterprises is a wider issue than "just" a question of installing inclusive governance mechanisms, since social enterprises have the characteristics needed to be contributing also to the shaping of norms, public policies, and the public sphere in general (Pestoff, Hulga, 2015, p. 1756).

The analysis of the results of the concept of social enterprises shows that various authors from different countries emphasise the same basic criteria for the concept of social enterprises which may be summarised as the economic dimension of a legal entity for ensuring economic activity of the entity, the social dimension - for the implementation of social policy of the entity and the governance-political dimension for the state support for social enterprises and the most vulnerable part of the society of the country (see Figure 2).

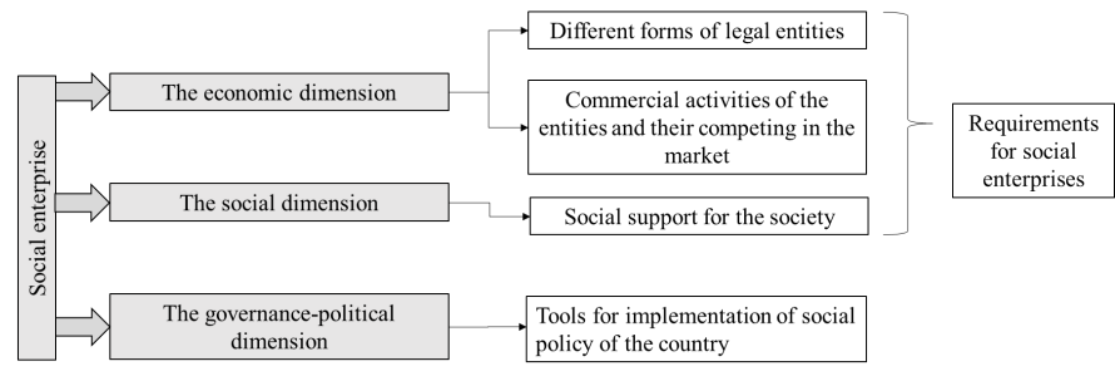

Fig. 2. The concept of a social enterprise Source: composed by authors

Therefore, the concept of a social enterprise has to meet three core elements: be active as a legal entity, implement social policy of the entity and the social - political policy of the country.

\section{The status of social enterprises in Lithuania}

Social enterprises in the Republic of Lithuania are regulated under the Law of social enterprises, issued on 1 June, 2004, No IX-2251. The law stipulates that the purpose of social enterprises is to employ persons who have lost their professional and general employability, are inactive economically, unable to compete on the labour market on equal terms, to encourage their return to the labour market, to reinforce their social integration and to reduce social exclusion. The legal requirements for social enterprises and their types are presented in Figure 3. 


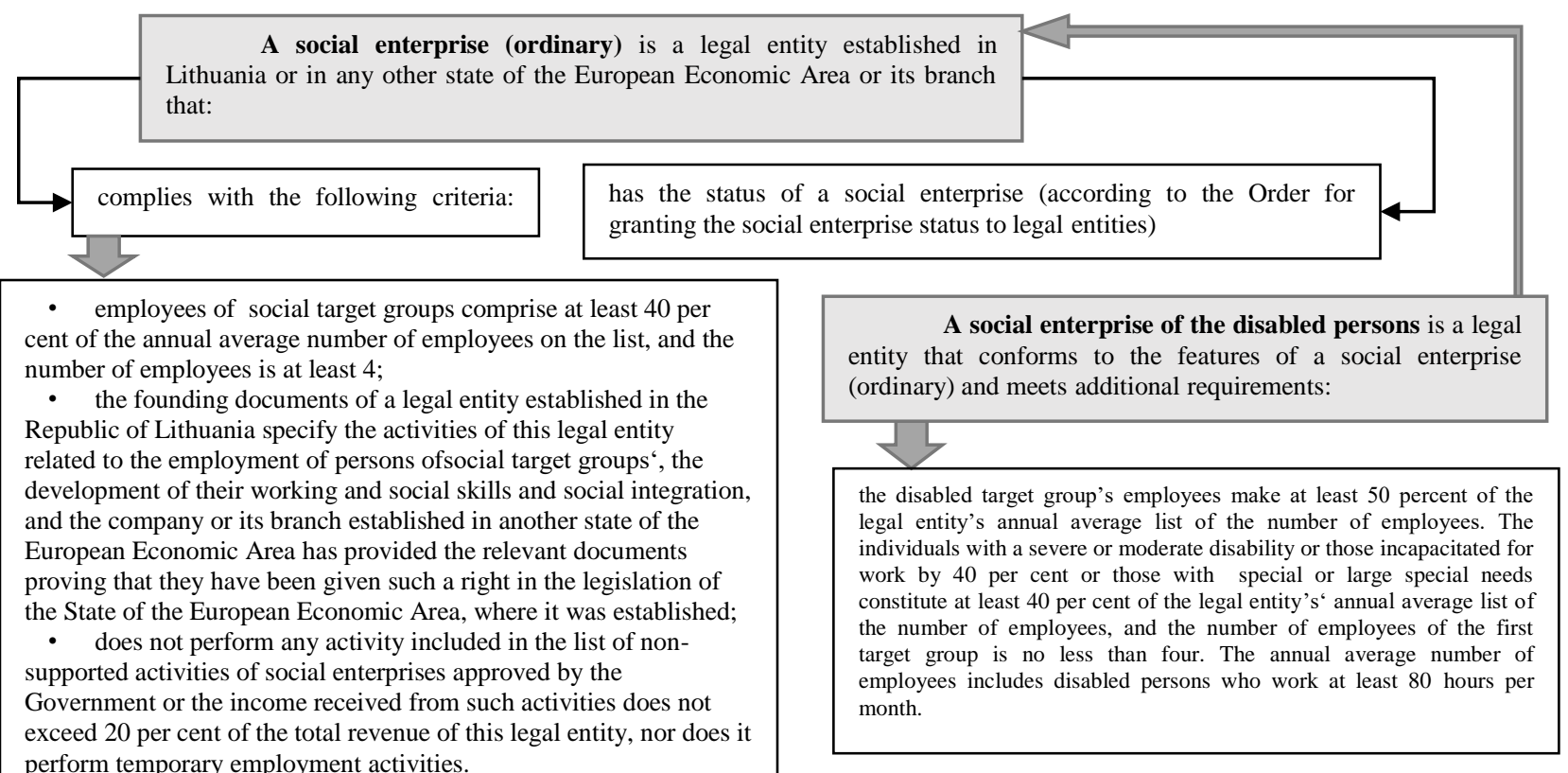

Social target groups

1. disabled persons with a mild, moderate or severe disability, or disabled persons who have been diagnosed with a level of incapacity of $55 \%$ or a high, medium or low level of special needs,

2. long-term unemployed whose unemployment duration is longer than two years from the date of registration at the Territorial Labour Exchange;

3. persons over 50 years of age, registered as unemployed by the Territorial Labour Exchange;

4. the mother/father (adoptive parent) of the child, a single parent in raising a child (adoptive child) up to eight years or a disabled child (adoptive child) under 18 years of age, or any other person who cares for a sick or disabled family member who has a special need for permanent nursing or continuous care (assistance) if the duration of unemployment since the date of registration in the territorial labour exchange is longer than six months;

5. persons who have returned from places of imprisonment when the period of imprisonment has been more than six months, have been registered at the territorial labour exchange no later than within six months after their release from the date of correctional institutions, and if this registration period is no less than six months;

6. persons who are dependent on narcotic, psychotropic and other psychoactive substances after completing psychological social and (or) professional rehabilitation programmes if the duration of unemployment from the date of registration in the Territorial Labour Exchange is longer than six months.

Fig. 3. Types and requirements of social enterprises

Source: composed by authors according to Lietuvos Respublikos socialinių įmonių ịstatymas, 2017; Socialinès įmonės, 2018.

According to Figure 3, in general, social enterprises are legal entities that employ persons of social target groups who develop their working and social skills and social integration and who do not perform activities included in the list of non-supported activities in Lithuania.

In 2016 there were 172 social enterprises, 65 of them were social enterprises of disabled persons in Lithuania. Those enterprises employed 6,408 employees of special groups and 6,246 of them were disabled persons. Approximately 14 per cent of disabled persons work in social enterprises (SADM viceministre, 2017). Table 1 presents the number and employment of disabled persons. 


\section{ENTREPRENEURSHIP AND SUSTAINABILITY ISSUES}

ISSN 2345-0282 (online) http://jssidoi.org/jesi/

2019 Volume 6 Number 3 (March)

http://doi.org/10.9770/jesi.2019.6.3(7)

Table 1. The number and employment of disabled persons

\begin{tabular}{|l|c|c|c|}
\hline $\begin{array}{c}\text { Number of disabled persons / } \\
\text { Year }\end{array}$ & 2015 & 2016 & 2017 \\
\hline Overall & 205,895 & 201,664 & 198,610 \\
\hline Working age & 138,465 & 135,680 & 135,130 \\
\hline Employed persons & 47,335 & 48,256 & 47,133 \\
\hline Employment (\%) & 34.19 & 35.57 & 34.88 \\
\hline
\end{tabular}

Source: Neigalumo statistika ir dinamika 2017

As of 1 August 2018, 142,700 unemployed persons (8.2 per cent of the working age population) in Lithuania were registered at the Lithuanian Labour Exchange. The number of the registered unemployed persons is presented in Table 2.

Table 2. The number of unemployed persons

\begin{tabular}{|l|c|c|c|c|c|}
\hline Average number per year / Year & 2013 & 2014 & 2015 & 2016 & 2017 \\
\hline $\begin{array}{l}\text { Total number of unemployed } \\
\text { persons }\end{array}$ & 201,322 & 173,006 & 158,153 & 144,864 & 139,615 \\
\hline Number of disabled persons & 12,432 & 11,434 & 10,949 & 10,376 & 9,927 \\
\hline $\begin{array}{l}\text { Number of long-term unemployed } \\
\text { persons }\end{array}$ & 57,122 & 58,167 & 46,905 & 40,177 & 36,916 \\
\hline
\end{tabular}

Source: Bedarbių struktūros pokyčiai, 2018

Table 2 shows that average number of the registered unemployed persons comprised more than 163 thousand persons during the last five years and the level of the indicator decreased by almost $10 \%$ per year from 2013 . The average number of the unemployed disabled persons was 11,023 with the annual decline of the indicator of around 5\%. The average rate of the number of long-term unemployed persons comprises around one third of the total number of unemployed persons with an average decrease of around $11 \%$ per year over the period from 2013 through 2017. The overall decline of all the indicators reflects an upward trend of growing economy in Lithuania.

The Seimas of the Republic of Lithuania and the Government of the Republic of Lithuania in cooperation with the Ministry of Social Security and Labour of the Republic of Lithuania are developing a policy of employment promotion and social support. This policy is implemented by the branches of the Lithuanian Territorial Labour Exchange, municipalities and their institutions (Aktyvios darbo rinko..., 2017).

According to their special status, social enterprises may receive state support: partial compensation of wages and social insurance contributions; a subsidy for the creation or adaptation of workplaces for disabled workers and the purchase or adaptation of their work equipment; a subsidy for training staff belonging to social target groups. Social enterprises of disabled persons may apply for additional state support: subsidy for adaptation of working environment, manufacturing and rest premises; subsidy for additional administrative and transport expenses; subsidy for the expenses of an assistant (sign language translator) (Socialinės įmonès, 2018; Lietuvos Respublikos socialinių įmonių įstatymas, 2017). For research purposes, social enterprises (ordinary) and social enterprises for disabled persons will be generally called as social enterprises and will not be analysed separately. The dynamics of state support for social enterprises is presented in Table 3. 


\section{ENTREPRENEURSHIP AND SUSTAINABILITY ISSUES}

ISSN 2345-0282 (online) http://jssidoi.org/jesi/

2019 Volume 6 Number 3 (March)

http://doi.org/10.9770/jesi.2019.6.3(7)

Table 3. State support for social enterprises

\begin{tabular}{|c|c|c|c|c|c|c|c|c|c|c|}
\hline 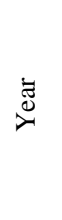 & 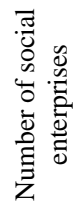 & 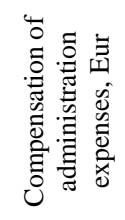 & 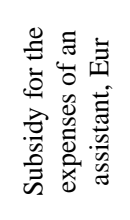 & 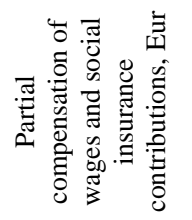 & 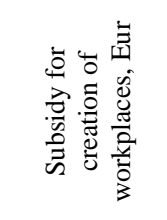 & 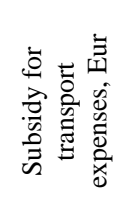 & 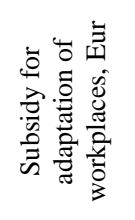 & 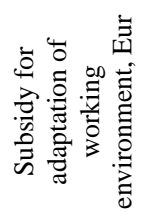 & 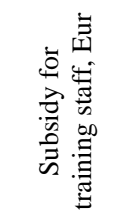 & 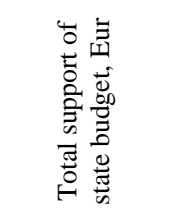 \\
\hline 2013 & 134 & 890.28 & 11481.30 & 4242659.36 & 272981.21 & 47700.33 & 11360.06 & 0.00 & 12638.99 & 4599711.52 \\
\hline 2014 & 141 & 831.94 & 21556.11 & 5104695.52 & 400767.12 & 50303.34 & 5931.42 & 0.00 & 0.00 & 5584085.45 \\
\hline 2015 & 148 & 944.09 & 0.00 & 4423542.66 & 1164966.72 & 40763.10 & 7700.00 & 38491.17 & 540.00 & 5676947.74 \\
\hline 2016 & 172 & 1024.93 & 26315.96 & 9992363.94 & 1197571.25 & 31036.74 & 0.00 & 29978.68 & 26513.33 & 11304804.83 \\
\hline 2017 & 189 & 532.71 & 48373.13 & 16720286.84 & 2850812.26 & 23093.05 & 0.00 & 31497.90 & 0.00 & 19674595.89 \\
\hline
\end{tabular}

Source: The Lithuanian Labour Exchange, 2018

It is obvious that the largest part of state support ( $87 \%$ on average) is assigned to partial compensation of wages and social insurance contributions. State support for creation of working places varies from almost $6 \%$ to almost $21 \%$ and comprises on average around $12 \%$ of the total amount of state support for social enterprises. Other types of state support do not exceed 1\%. Over the last five years an average increase of 3768721 Eur or 28\% per year is observed in the total amount of state support for social enterprises. The largest increase of state support for social enterprises was recorded in 2016 and 2017 (almost 50\% and 43\%, accordingly). This trend might have triggered political discussions on state support tools for social enterprises and the changes introduced to Law on Corporate Income Tax and Law on Social Enterprises.

The Law on Social Enterprises determines social target groups of employees, the types, the requirements for social enterprises, rights and obligations, status of social enterprises, state support for social enterprises. On 28 June 2018, the Law on Amendments of the Law on Social Enterprises was passed, which decreased the limits of state support for social enterprises (Lietuvos Respublikos socialinių įmonių įstatymo..., 2018). The amendments were related with the types of state support, which comprise the largest part of the total amount of state support: compensation of wages and social insurance contributions decreased from 2 to 1.55 of the minimum monthly wages; the subsidy for the creation of workplaces - from the amount of 40 to 31.03 of the minimum monthly wages; the subsidy for adaptation of workplaces, working environment - from amount of 6 to 4.65 of the minimum monthly wages. The amendments will come into force on 01 January 2019.

The Law on Corporate Income Tax (Lietuvos Respublikos pelno mokesčio ịstatymas..., 2017) stipulates the general terms of corporate income tax as well as some exemptions for particular types of activities, micro enterprises, public companies, etc. The standard corporate income tax rate in Lithuania is 15\%. Although enterprises whose turnover for the fiscal period is less then 300,000 Eur, those who have less then 10 employees and meet the control conditions of other enterprises may pay 5\% of corporate income tax. Apart from that, nonprofit entities whose revenue from commercial activities for the fiscal period does not exceed 300,000 Eur, part of the profit, which consists of 7,250 Eur, is taxed by $0 \%$ rate of corporate income tax, and the remaining part of the taxable profit - by the tax rate of $15 \%$. When calculating the income of commercial activity, non-profit entities do not include income which is directly allocated to meet the public interest activities. The exemptions for non-profit entities have taken effect since 2010. The profit of social enterprises was taxed by $0 \%$ rate from 2009 to 2018 (the exemption was repealed under a political initiative (Lietuvos Respublikos pelno mokesčio įstatymas..., 2017)). The Law on corporate income tax also determines the exemptions related to the incurred expenses, different types 


\section{ENTREPRENEURSHIP AND SUSTAINABILITY ISSUES}

ISSN 2345-0282 (online) http://jssidoi.org/jesi/

2019 Volume 6 Number 3 (March)

http://doi.org/10.9770/jesi.2019.6.3(7)

of assets, loss transfer etc., but the evaluation of such exemptions is not possible, as the internal information of the enterprises is necessary.

The disabled and other persons of the social target groups are the most vulnerable part of the society of any country and the decrease of tax exemptions or the state support for business which involve such persons into different activities should be assessed in all possible aspects as the changes may limit the possibilities of social enterprises to continue such initiative, with this, to continue employment of marginalised population. According to N.L. Maxwell, D. Rotz (2017) by integrating a business mission into a transitional jobs programme, employment social enterprises provide temporary work and a supported work environment to reduce the barriers facing disadvantaged workers while generating revenue to cover production costs (Maxwell, Rotz, 2017).

In Lithuania, most private limited liability companies and public companies have the status of social enterprises. J. Čižikienè, A. Urmanavičienè- Čižikaitè (2013) analysed social enterprises in Europe and made conclusions that the forms of social enterprises are different in all EU Member States - cooperatives (different forms in Sweden, Italy, Great Britain), mutual societies, associations, foundations. Various forms of social enterprises are implemented in France, Belgium, and Portugal. Social enterprises cover a wide range of services and manufacturing market spectrum. They can provide services for a vulnerable part of the society and ensure social and professional integration through employing people who have found themselves at a disadvantage, are experiencing social exclusion, are without appropriate professional qualifications or have social problems (Čižikienè, Urmanavičienè- Čižikaitè, 2013, p. 27). Moreover, although the number of social enterprises is not significant, their role in social environment and policy of the country is major. This role inspires the need to evaluate the changes of legislation on the state budget of Lithuania.

\section{Research results}

During the third phase of the research, the total amount of profit and alternative corporate income tax were calculated in order to evaluate how much of corporate income tax could social enterprises have paid during the research period (see Figure 4).

Figure 4 shows several options of possible corporate income tax payments: corporate income tax calculated as $15 \%$ of the profit (see Formula 1), adjusted corporate income tax calculated according to tax exemptions (see Formula 2), for enterprises with the appropriate amount of turnover and number of employees, and public entities (see Formula 3), and the difference between the possible corporate income tax payment options. Over the period under analysis, social enterprises earned profit on average in the amount of 12610000 Eur and could have paid almost 1900000 Eur of corporate income tax per year if social enterprises did not apply corporate income tax incentive for social enterprises. Nevertheless, if social enterprises do not apply tax exemptions for the social enterprises, they might apply corporate income tax exemptions for enterprises with the appropriate amount of turnover and the number of employees, or exemptions for public entities. The recalculation of the adjusted corporate income tax according to the exemptions show that on average more than 1600000 Eur of corporate income tax per year would be paid and the adjusted corporate income tax rate would make around $12.43 \%$. The largest impact on such results was observed in 2013, as the adjusted corporate income tax rate for that year was $4.38 \%$. These results may be influenced by the consequences of the global economic crisis of 2008. If the results of 2013 were eliminated the average adjusted corporate income tax rate would be $14.44 \%$.

Formula 1 for the calculation of $15 \%$ corporate income tax:

Corporate income tax $(15 \%)=$ prof it $* 0.15$, where

profit - is the sum of the profit of all the analysed social enterprises. The calculations have not included loss. 
ENTREPRENEURSHIP AND SUSTAINABILITY ISSUES

ISSN 2345-0282 (online) http://jssidoi.org/jesi/

2019 Volume 6 Number 3 (March)

http://doi.org/10.9770/jesi.2019.6.3(7)

Formula 2 for the calculation of the adjusted corporate income tax, according to corporate income tax exemptions for enterprises with a turnover of less than 300,000 Eur, less than 10 employees and they meet some conditions of the control of other enterprises:

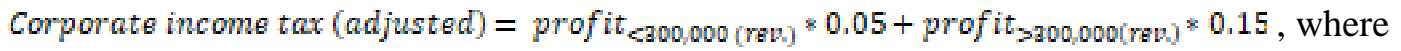

profit $t_{<00,000(\mathrm{ren})} * 0.05$ - is the sum of the corporate income tax of all the social enterprises whose turnover for the fiscal period was less than 300,000 Eur.

profit $t_{3800000(\text { rew })} * 0.15$ - is the sum of the corporate income tax of all social enterprises whose turnover for the fiscal period was more than 300,000 Eur.

Formula 3 for the calculation of the adjusted corporate income tax for public entities (PE), according to corporate income tax exemptions for public entities:

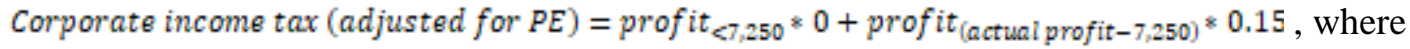

profit $\mathrm{c}_{250} * 0$ - is zero, as profit (or part of the profit) of public entities below 7,250 Eur is taxed by corporate income tax rate of $0 \%$.

profit $_{\left.\text {[actual profit }-7_{2} 250\right) * 0.15}$ - is the sum of the corporate income tax of public entities for the part of profit, which exceeds 7,250 Eur.

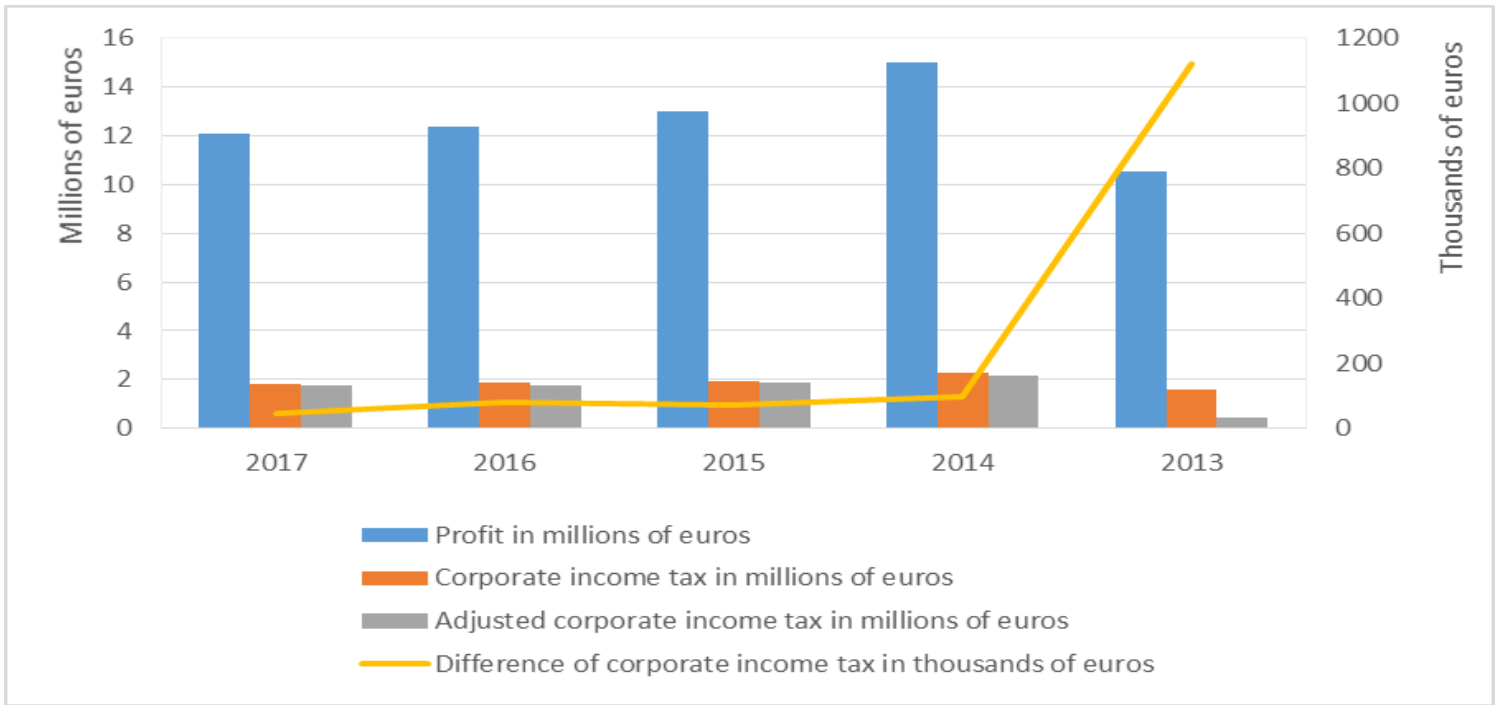

Fig. 4. Analysis of the possible corporate income tax payment options Source: composed by authors according to the research results

Taking into account that the difference between both possible corporate income tax payment options is not significant and the probability that social enterprises will apply other forms of corporate income tax exemptions (if not the exemption for social enterprises) is extremely high, the adjusted corporate income tax will be used for further research. Corporate income tax exemptions influence the state income of corporate income tax which makes around $10 \%$ of the total state budget revenue (our calculations did not include the state budget revenue the EU and other organisations support). Figure 5 presents the comparison of the adjusted corporate income tax and the state revenue of corporate income tax. The comparison of the results show that possible adjusted corporate income tax payments carried out by social enterprises would comprise on average around $0.3 \%$ of the state income of corporate income tax during the period under analysis. This percentage may be evaluated as insignificant and unable to make a significant impact on the state budget's revenue of corporate income tax. 


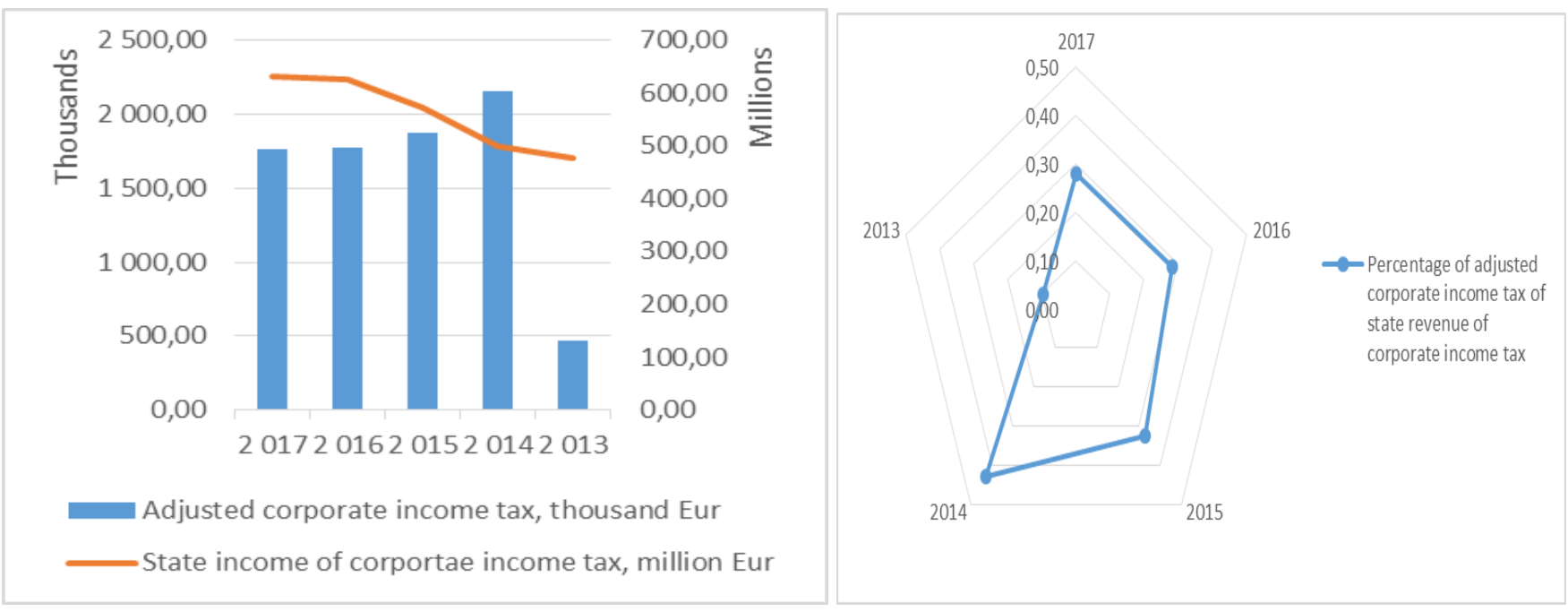

Fig. 5. Comparison of the adjusted corporate income tax and the state income of corporate income tax Source: composed by authors according to the research results and Valstybès biudžeto vykdymo duomenys, 2018

As mentioned above, social enterprises are able to receive the state support of different types from the state budget (see Table 2). On average the total amount of the state support for social enterprises comprised $0.16 \%$ of the state budget during the period under analysis, but rapidly increased from 2016 and in 2017 and made $0.33 \%$. Even such value of the state support for social enterprises may not be evaluated as significant, but the increasingly growing trends initiated the amendments of legislation and were limited by the changes in the Law on social enterprises. The structure of the total amount of reliefs (exemptions), including corporate income tax exemptions and state support, and the percentage of the state budget is presented in Figure 6. The state support made on average around 83\%, and in 2013 and 2017 exceeded 90\% that comprised the largest part of the total amount of reliefs. Over the last five years the total amount of reliefs for the state budget covered on average $0.18 \%$, with the lowest level of $0.09 \%$ in 2013 and the highest $-0.34 \%$. in 2017 .

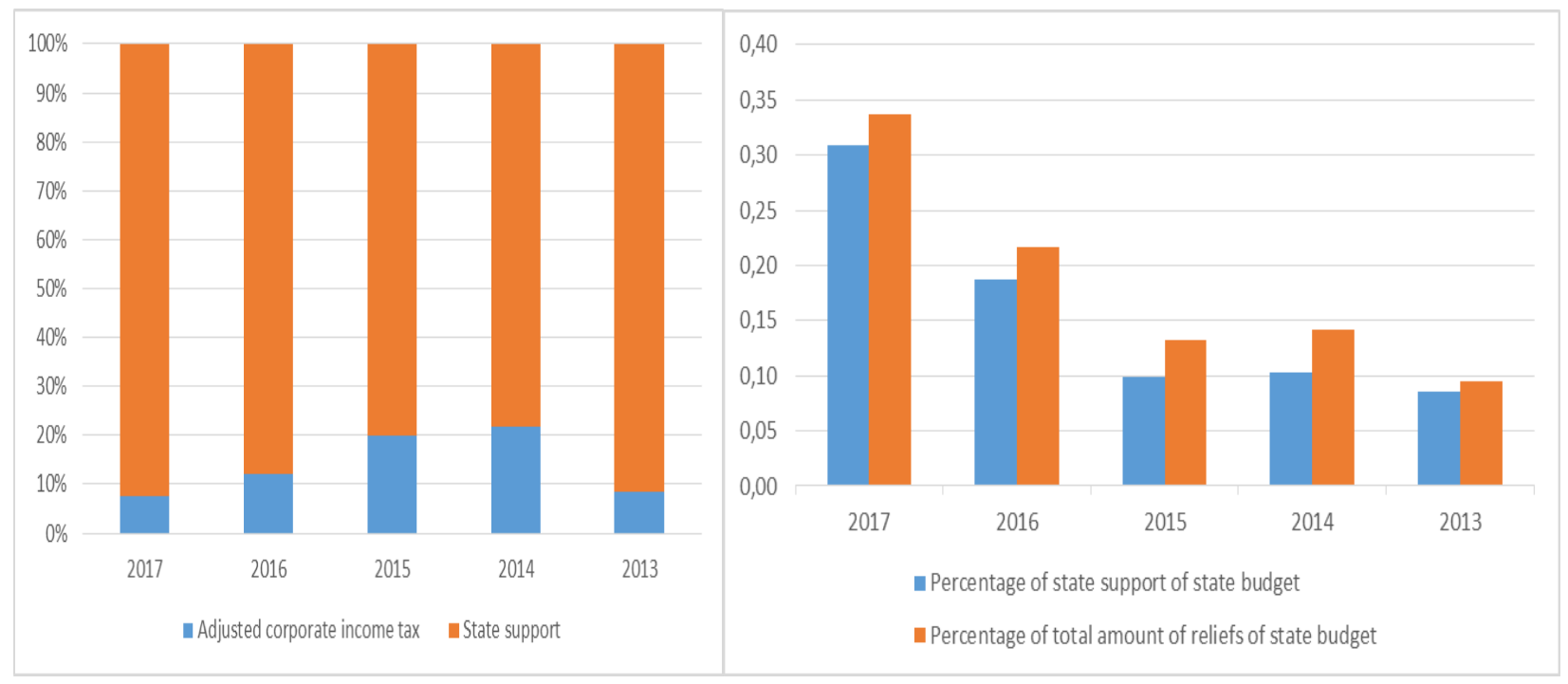

Fig. 6. Structure of the total amount of reliefs for social enterprises and the percentage in the state budget Source: composed by authors according to the research results and Valstybės biudžeto vykdymo duomenys, 2018; The Lithuanian Labour Exchange, 2018. 


\section{ENTREPRENEURSHIP AND SUSTAINABILITY ISSUES}

ISSN 2345-0282 (online) http://jssidoi.org/jesi/

2019 Volume 6 Number 3 (March)

http://doi.org/10.9770/jesi.2019.6.3(7)

The political initiative to reduce the support for social enterprises may be grounded by a double increase of the total amount of reliefs for social enterprises during 2016-2017 but still the highest percentage of the total amount of the state budget in 2017 may be evaluated as insignificant and should be evaluated generally including the impact of the elimination of reliefs on social policy and the condition of persons of social target groups.

For social enterprises, traditional donations and grants (non-earned income) remain an important source of revenue. Non-earned income is an attractive and useful revenue source for all social enterprises because it is not repayable and does not give any explicit and enforceable control or voting rights to donors. It also enables social enterprises to pursue activities without income-generating potential - i.e. value-creating as opposed to valuecapture activities. Moreover, young and growing social enterprises are often unable to secure alternative funding such as loans, investment funds and capital; hence, non-earned income is their only option (Liston-Heyes et al 2016).

A. Szymanska and M. Jegers (2016) research results on the optimal solution show that social enterprises have a strong potential to realise their social mission and to run sufficiently profitable business at the same time. They have proved that, in the short-term, the social enterprise is motivated in reinvesting its profits in the process of the social mission realisation but authors can expect that in the long-term (applying a dynamic framework) the social enterprise might also be interested in keeping some savings for its strategic investments. The authors conclude that the optimal allocation between labour and debt, both necessary for social production, has a significant impact on the social mission realisation (Szymanska, Jegers, 2016, p. 514).

It may be summarised, that state support provided by different tools is important and significant for social enterprises and plays an important role for the development of the activity of social enterprises, although the research results show that the value of corporate income tax exemptions and state support is not significant in terms of state budget of Lithuania. Therefore, the research included general evaluation of different forms of state support for social enterprises and their impact on state budget of Lithuania, the direction for further research of social enterprises in Lithuania may be related to the evaluation of the dynamics of employment of persons of social target groups as well as the total amount of relief level in the long term, which would reflect the implementation of legislation amendments and the condition of persons of social target groups.

\section{Conclusions}

The concept of a social enterprise may be concluded in three dimensions: economic dimension - as an active legal entity, social dimension - as an implementer of social policy and governance-political dimension - as part of social policy of the country. In Lithuania, the procedure of granting of the status of a social enterprise requires that the enterprises are subject to special obligations as they are legal entities who employ persons who have lost their professional and general employability, are inactive economically, unable to compete on the labour market on equal terms with other employees, develop their working and social skills and social integration, and do not perform the activities included in the list of non-supported activities.

Social enterprises may receive different types of state support in Lithuania. The largest part of state support involves partial compensation of wages and social insurance contributions (approximately 87\%). The state support for the creation of working places makes on average around $12 \%$, other types of state support do not exceed $1 \%$. Over the last five years, the total amount of the state support for social enterprises was increasing on average by $28 \%$ per year.

The results of comparison of adjusted corporate income tax and state income of corporate income tax show that possible payments of adjusted corporate income tax of social enterprises may be evaluated as insignificant and 


\section{ENTREPRENEURSHIP AND SUSTAINABILITY ISSUES}

ISSN 2345-0282 (online) http://jssidoi.org/jesi/

2019 Volume 6 Number 3 (March)

http://doi.org/10.9770/jesi.2019.6.3(7)

over the analysed period would make on average around $0.3 \%$ of the state income of corporate income tax. The total amount of the state support for social enterprises in the state budget comprised on average $0.16 \%$ but accelerated in 2016 and reached $0.33 \%$ in 2017. The evaluation of the structure of the total amount of reliefs (exemptions) and the percentage of the state budget show that the largest part of the total amount of reliefs for social enterprises which includes corporate income tax exemptions and state support, comprised state support - in average around 83\% during analysed period and exceeded 90\% in 2013 and 2017. The total amount of reliefs comprised on average approximately $0.18 \%$ of the state budget.

The research results show that in terms of state budget of Lithuania, the value of corporate income tax exemptions and state support is not significant. Nevertheless, the state support provided by different tools is important and significant for social enterprises and plays an important role in the development of the activities of social enterprises. The direction for further research of social enterprises in Lithuania may be related with the evaluation of the dynamics of employment of persons of social target groups as well as the level of the total amount of reliefs in the long term. The increase of the value of state support in 2016 and 2017 may be evaluated unfavourably, but the suggestions for an additional control of the provision of status of social enterprises and their social activity may limit the misuse of state support. The cancelation of corporate income tax incentive for social enterprises is even less significant in the measurement of the total amount of reliefs and does not play an essential role in the state budget as it comprises only approximately $0.03 \%$. Therefore, the general reduction of state support and corporate income tax exemptions may limit the possibilities of social enterprises to reinvest their profits, expand business and employment of marginalised population.

\section{References}

Aktyvios darbo rinkos politikos priemonių ir socialinès paramos suderinimo integruojant nedirbančius asmenis ị darbo rinką tobulinimo tyrimas (Research on Development of Coordination of Active Labor Market Policy Measures and Social Support for Integrating of Unemployed Persons to Labor Market) / Ministry of Social Security and Labour of the Republic of Lithuania. 2017. Retrieved from https://socmin.lrv.lt/uploads/socmin/documents/files/veiklos-sritys/darbas/darborinka/TYRIMAI/2017\%20adrpp\%20ir\%20soc_\%20paramos\%20suderinamumo\%20tyrimas\%2C\%20civitta.pdf.

Arena, M., Azzone, G., Bengo, I. 2015. Performance Measurement for Social Enterprises. VOLUNTAS: International Journal of Voluntary and Nonprofit Organizations 26(2): 649-672. https://doi.org/10.1007/s11266-013-9436-8

Bedarbių struktūros pokyčiai [Changes in the structure of the unemployed persons]/ Lithuanian Labour Exchange. 2018. Retrieved from http://www.ldb.lt/Informacija/DarboRinka/Puslapiai/rodikliai_men_pabaigoje.aspx.

Chan, A. 2016. Personal Wellbeing of Participants of Social Purpose Enterprises: The Influence of Social Support. Voluntas: International Journal Of Voluntary \& Nonprofit Organizations 27(4): 1718-1741. https://doi.org/10.1007/s11266-015-9637-4

Cho, Y.-Ch., Jang, J.-H. 2014. Analysis of Current Conditions Facing Social Enterprises in Korea: Policy Issues Regarding Their Sustainable Development. International Journal of Business and Social Research (IJBSR) 4(3): 119-125. http://dx.doi.org/10.18533/ijbsr.v4i3.460, https://thejournalofbusiness.org/index.php/site/article/view/460/349.

Čižikienė, J., Urmanavičienė-Čižikaitè, A. 2013. Socialinių įmonių plètros kryptys Lietuvoje [Social Enterprises Development Trends in Lithuania]. Kaimo raidos kryptys žinių visuomeneje: mokslo darbai 1(5): 17-27. http://talpykla.elaba.lt/elabafedora/objects/elaba:6092096/datastreams/MAIN/content.

Database of Credit Bureau "Creditinfo". 2018. Information provided under special request.

Gidron, B., Monnickendam-Givon, Y. 2017. A social welfare perspective of market-oriented social enterprises. International Journal of Social Welfare 26(2): 127-140. https://doi.org///doi:10.1111/ijsw.12232 


\section{ENTREPRENEURSHIP AND SUSTAINABILITY ISSUES}

ISSN 2345-0282 (online) http://jssidoi.org/jesi/

2019 Volume 6 Number 3 (March)

http://doi.org/10.9770/jesi.2019.6.3(7)

Lietuvos Respublikos pelno mokesčio ịstatymas [the Law on Corporate Income Tax of the Repubic of Lithuania] 20 December, 2001, No

IX-675 under amendments as to 07 December, 2017. 2017. Retrieved from https://www.e-

tar.lt/portal/lt/legalAct/TAR.A5ACBDA529A9/OOOxbMuoLg.

Lietuvos Respublikos socialinių įmonių įstatymas [the Law on Social Enterprises of the Repubic of Lithuania] ], 1 June, 2004 No IX-2251 under amendments as to 21 December, 2017. 2017. Retrieved from https://www.e-

$\underline{\text { tar.1t/portal/lt/legalAct/cc975670ec6d11e78a1adea6fe72f3c5. }}$.

Lietuvos Respublikos socialinių įmonių įstatymo Nr. IX-2251 14, 15, 17 ir 19 straipsnių pakeitimo ịstatymas [the Law on amendments of 14, 15, 17 and 19 articles of the Law on social enterprises]. 2018. Retrieved from https://www.e-

tar.1t/portal/lt/legalAct/0a4163d0801b11e8ae2bfd1913d66d57.

Liston-Heyes, C., Hall, P.V., Jevtovic, N., Elson, P.R. 2016. Canadian Social Enterprises: Who Gets the Non-Earned Income?

VOLUNTAS: International Journal of Voluntary and Nonprofit Organizations December 28(6): 2546-2568.

https://doi.org/10.1007/s11266-016-9787-z

Lithuanian Labor Exchange. 2018. Information provided under special request.

Maxwell, N.L., Rotz, D. 2017. Potential Assistance for Disadvantaged Workers: Employment Social Enterprises. Journal of Labor Research 38(2): 145-168. https://doi.org/10.1007/s1212, https://link.springer.com/article/10.1007/s12122-017-9248-5.

Miles, M.P., Verreynne, M.-L., Luke, B. 2014. Social Enterprises and the Performance Advantages of a Vincentian Marketing Orientation. Journal of Business Ethics 123(4): 549-556. https://doi.org/10.1007/s10551-013-2009-3, https://link.springer.com/article/10.1007/s10551$\underline{013-2009-3}$

Neigalumo statistika ir dinamika [Disability statistics and dynamics] / Ministry of Social Security and Labour of the Republic of Lithuania. 2017. Retrieved from https://socmin.lrv.lt/lt/veiklos-sritys/socialine-integracija/neigaliuju-socialine-integracija/statistika-2.

Pestoff, V., Hulgård, L. 2016. Participatory Governance in Social Enterprise. Voluntas: International Journal of Voluntary \& Nonprofit Organizations 27(4): 1742-1759: http://doi:10.1007/s11266-015-9662-3

Ramus, T. Vaccaro, A. 2017. Stakeholders Matter: How Social Enterprises Address Mission Drift. Journal of Business Ethics 143(2): 307322. https://doi.org/10.1007/s1055, https://link.springer.com/article/10.1007/s10551-014-2353-y.

SADM viceministrè: „Neịgaliųjų įdarbinimas socialinėse įmonėse turès būti efektyvesnis“ [Vice-Minister of the MSSL "Recruitment of disabled persons in social enterprises will have to be more efficient"] / Ministry of Social Security and Labour of the Republic of Lithuania. 2017. Retrieved from https://socmin.lrv.lt/lt/naujienos/sadm-viceministre-neigaliuju-idarbinimas-socialinese-imonese-tures-butiefektyvesnis.

Situation in labour market / Lithuanian Labour Exchange. 2018. Retrieved from http://www.ldb.lt/EN/INFORMATION/LABOURMARKET/Pages/situation_review.aspx.

Social enterprise / EMES - international research network. 2018. Retrieved from https://emes.net/focus-areas/.

Socialinès įmonès (Social Enterprises) / Ministry of Social Security and Labour of the Republic of Lithuania. 2018. Retrieved from https://socmin.lrv.lt/lt/veiklos-sritys/darbo-rinka-uzimtumas/uzimtumo-ir-darbo-rinkos-politika/socialinesimones\#Socialini\%C5\%B3\%20\%C4\%AFmoni\%C5\%B3\%20prie\%C5\%BEi\%C5\%ABra.

Szymanska A, Jegers M. 2016.Modelling Social Enterprises. Annals of Public and Cooperative Economics [serial online]. December 87(4): 501-527. Available from: EconLit with Full Text, Ipswich, MA. Retrieved from http://web.b.ebscohost.com/ehost/pdfviewer/pdfviewer?vid=2\&sid=8fae66d5-fefd-4225-9966-f9e7c3fdd620\%40sessionmgr103.

Valstybės biudžeto vykdymo duomenys [Data on the Implementation of the State Budget] / Ministry of Finance of the Republic of Lithuania. 2018. Retrieved from http://finmin.lrv.lt/lt/veiklos-sritys/biudzetas/valstybes-biudzeto-vykdymo-duomenys-1. 


\section{ENTREPRENEURSHIP AND SUSTAINABILITY ISSUES}

ISSN 2345-0282 (online) http://jssidoi.org/jesi/

2019 Volume 6 Number 3 (March)

http://doi.org/10.9770/jesi.2019.6.3(7)

Short biographical note about the contributors at the end of the article (name, surname, academic title and scientific degree, duties, research interests):

Dr. Rasa SUBAČIENĖ is Professor at the Department of Accounting and Audit, Faculty of Economics and Business Administration, Vilnius University, Lithuania. She is a member of editorial boards of the following journals: "ETAP: Economic Theory, Analysis, Practice"; "Latgale National Economy Research"; "Science and Studies of Accounting and Finance: Problems and Perspectives". Research Interests: Financial Accounting, Management Accounting, Analysis of Activity of Enterprises.

ORCID ID: orcid.org/0000-0001-6559-8478

Dr. Ramunė BUDRIONYTE் is Assistant Professor in the Accounting and Auditing Department at Faculty of Economics and Business Administration, Vilnius University. She is a member of the Committee of Business Accounting Standards under the Ministry of Finance of the Republic of Lithuania. Her teaching curriculum and research interests involve International Accounting Standards, Financial Accounting, Financial Analysis, Financial Reporting, Taxes.

ORCID ID: orcid.org/0000-0002-6889-5598

Dr. Aida MAČERINSKIENĖ is Dean of the Faculty of Economics and Business Administration, Vilnius University, Professor in the Business Department. Scientific Interests: Tourism Management, Strategic Planning, International Project Management, Consumer Behaviour.

ORCID ID: orcid.org/0000-0002-0137-9388

Dr. Daiva TAMULEVIČIENĖ is Assistant Professor of Accounting and Auditing Department, Faculty of Economics and Business Administration, Vilnius University. Scientific Interests: Controlling, Management Accounting, Modern Cost Accounting Systems, Financial Management, Financial Analysis.

ORCID ID: orcid.org/0000-0002-0187-037X

Copyright (C) 2019 by author(s) and VsI Entrepreneurship and Sustainability Center

This work is licensed under the Creative Commons Attribution International License (CC BY).

http://creativecommons.org/licenses/by/4.0/

cC) (7) Open Access 